\title{
Study on the Approximation of the Albanian Electoral Legislation with the Code of Good Practice on Electoral Matters of the Venice Commission (EC)
}

\author{
PhD. Andon Kume
}

\author{
Lector, "Alexander Moisiu" University, Durrës, Albania
}

\author{
Doi:10.5901/ajis.2015.v4n2p77
}

Abstract

The Albanian electoral legislation generally reflects the requirments and recommendation of the Code of Good Practice in Electoral Matters of the Venice Commission (EC). The comparative analysis highlights the need for intervention in this legislation, in particular in matters relating to: (i) creating favorable conditions for exercising the right to vote for voters residing abroad, (ii) the equality of vote power and equal chances for subjects and candidates part of the electoral race, (iii) gender representation, (iv) facilities for voters with disabilites, (v) establishment ofreliable and impartial election bodies, (vi) decisionmaking by qualified majority or consensus of the election commissions, (vii) establishing an effective complaints system, (viii) increased opportunities for the involvement of the judicial system, District Courts and Constitutional Court in election issues.

Keywords: Election legal framework, Code, Good practice, Venice Commission

\section{Introduction}

On 8 November 2001 the Standing Committee of the Parliamentary Assembly, acting on behalf of the Assembly, adopted Resolution 1264 (2001) inviting the Venice Commission to draft a Code of Good Practice in Electoral Matters. ThisCode was approved by the Parliamentary Assembly of the Council of Europe at its 2003 session - 1st part and by the Congress of Local and Regional Authorities of Europe at its Spring session 2003.

It is based on five fundamental principles of the Europe's electoral heritage - universal, equal, free, secret and direct suffrage, and it underlines the necessity of elections to be held at regular intervals. This Code sets a set of guidelines drafting a legislative framework necessary to create the legal basis for free and fair elections and in compliance with international standards.

Albania as a member of the EC, has been continuesly assisted by Venice Commission, in its efforts to draft an election legislation compatible with the basic principles and legislative rules outlined in the Code of Good Practice in Electoral Matters [3,4].

The aim of this study is to analyze and assess the level of approximation of the Albanian electoral legislation with the Code of Good Practice in Electoral Matters. Its objective is the identification of gaps and needs for further improvement of the national legislation.

\section{Comparative Analysis to Assess the Level of Approximation of National Legislation with the Code of Good Practice on Electoral Matters}

This analysis was conducted referring to the five basic principles of the European electoral heritage, legislative rules recommendedby the Code of Good Practice in Electoral Matters and legislative solutions implemented inother national laws.

\subsection{Universal suffrage}

Universal suffrage means in principle that all human beings have the right to vote and to stand for election. This right may, however, and indeed should, be subject to certain conditions such as:

\subsubsection{Age}

Legislation should define a minimum age for the right to vote and to be elected. 
The Albanian legislation defines the age of 18 , the completion of which entitles the Albanian citizens to vote or te be elected.

\subsubsection{Nationality}

For ethnic minoritiesthe Albania Constitution foresees the same rights and duties as citizens of Albanian nationality. Consequently ethnicity is not a factor limiting the right to vote and to be elected.

\subsubsection{Residence}

The right to vote is not conditioned by citizen's residence. This right is recognized to all Albanian citizens, regardless of whether they reside in Albania or in other countries of the world.

Meanwhile, the residence is one of the most important information in preparing voters list.

The absence of the Citizen's Fundamental National Register andpopulation demographic movements within and outside the country, which, in general, are undeclared changes of residence, have always been factors with major effects in Voters List's drafting process, quality and completeness.According to the Albanian electoral legislation, in order to vote, citizens mus be registered on the voters list.

In drafting provisions addressing voter's list the "residence" notion has been one of the most controversial, giving spaces to different interpretations. So, these provisions use concepts such as

permanent residence, temporary residence, fundamental register of civil status, temporary registers of civil status etc.., and in in many cases they have generated heated political debates.

For immigrant's citizens, Albanian electoral legislation currently does not provide any restriction, unless for their registration in the voter's list. Meanwhile, it should be noted that according to the legislation the right to vote can be exercised only by being personally present at the polling station located in the electoral district where the voter is registered in the voters list.

\subsubsection{Deprivation of the right to vote and to be elected should be be clearly stated in the electoral legislation.}

The Electoral Code of the Republic of Albania [2] defines the cases when a citizen is deprived of the right to vote. This right is deprived only to Albanian citizens declared unable to act by a court final judgment. Meanwhile for being registered as a candidate the electoral code provides certain conditions. Among these condition can be mentioned, the obligation to present documentation for the preliminary support of the candidate, the residence of the candidate in the case of elections for the local government, as well as provisions limiting the right to be elected as a result of its incompatibility with other tasks exercised by the candidate, which are expressed in the Albanian Constitution [3].

\subsubsection{Voters List}

Electoral legislation, conditioning the right to vote by having voter's name on the voters list, must clearly define the procedures for compiling this list and the requirements that it must meet. The Code of Good Practice in Electoral Matters requires that:

(i) Voters list must be permanent

The implementation of the Citizens National Register, as an informatic product, has already created the necessary technical conditions, to complete this requirement. The Electoral Code provides the necessary procedures for the generation of voter lists at any time it is required.

(ii) Voter list should be updated regularly, at least once a year

This requirement is not yet reflected in the Albanian electoral legislation. While it should be noted that the Electoral Code adopted by Law no. 74/2012, dated 19.07.2012, contains provisions that create the necessary legal conditions in order to meet this requirement.

(iii) Voters list should be published

The Electoral Code adopted by Law no. 74/2012 dated 19.07.2012, provides for the publication of the final voters list, no later than 40 days before election day (Article 56, paragraph 1)

(iv) It should exist the opportunity for the implementation of an administrative procedure, which can be subject to judicial review or a judicial procedure for the registration of voters who are not registered. 
Article 55 of the Electoral Code provides for such administrative, judicial procedures that allow voters to register on the final voter list.

(v) A procedure mus be provided for correcting voters list if inaccuracies are verified Article 54 of the Albanian Electoral Code guarantees this right.

\subsubsection{Presentation of independent candidacies}

Presentation of independent candidates may be subject to the collection of a certain number of signatures. The law should not require collection of signatures of no more than 1 percent of the voters in the respective electoral zone. Verification of signatures should adhere to clear rules and their validity should be completed before the start of the campaign.

Articles 69-73 of the current Electoral Code, Law no. 74/2012, dated 19.07.2012, are relevant for meeting these requirements. Submission of supporting signatures is requested only for political parties that do not have any seats in the parliament.In this case the entities must submit a list of not less than 5,000 signatures of voters, nationally and in the subject is part of a coalition its candidates list must be supported by not less than 7000 voters, nationally. If the subject is an independent candidate he must submit a list of supporting signatures non less than 1 percent of the respective electoral zone but, in any case no more than 3,000 voters. This requirement is different for local elections. An indipendent candidate for mayor is required to ensure the support of 1 percent of the voters registered in the voters list of the respective local unit. The code requires voters to personally submit their signatures in the standard form. The form must contain the full identity of the voter, his date of birth and contact phone number. Along with the signing, each voter must submits a copy of a valid identification card, signed by him, which is attached to the list. Signatures verification is conducted by the administration of the CEC for parliamentary elections and for localelections this task is carried out by the respective CEAZ. According to the law this process must verify whether 5 percent of the supportersreside in the respective constituency at the time of filing the form.

\subsection{Equal suffrage}

2.2.1 Each voter has in principle one vote, where the electoral system provides voters with more than one vote, each voter has the same number of votes.

According to the electoral system applicable in Albania (regional proportional system) each voter votes with a ballot (article 105 para 3). For local elections each voter votes with two ballots.

\subsubsection{Equal voting power.}

This requires a balanced distribution of mandates between the various electoral areas, taking into account the criteria: number of people (including minors), number of registered voters, number of actual voters or combinations of these numbers.

The Constitution of Albania (Article 64) states that the Assembly consists of 140 members, elected by proportional system with multi-candidaciesconstituencies. Each district is defined as a constituency. Althugh the provision establishing criteria and procedures for the allocation of the number of seats among the constituencies is based on one of the criteria recommended by the Code of Good Practice in Electoral Matters, referring to the demographic characteristics of different regions of Albania, the procedure brings deviation from the vote equality principle. Inconstituencies located at north,northeast of Albania, where the number of voters is relatively small and the rapport - total number of citizens with residence in the respective constituency / voters number, is relatively large, the vote power differs significantly from that of other areas of the country. The Code of Good Practice takes into consideration a deviation of no more than 10 percent, and of course it should not be higher than 15 percent, except for rare cases (protection of a concentrated minority, administrative unit with very low population). The analysis shows that the rule laid down in the relevant provision (Article 75) have overlooked this request.

The mandate calculation for each electoral entities (Article 162), which, in accordance with the relevant provision is made using the formula D'Hond and the distribution of seats within the coalitions, (Article 163) which is based on theSantEgue formula, affetcs negatively the vote power. This calculation method penalizes parties that are not part of a coalition but run alone in elections. 


\subsubsection{Equality of opportunity}

The Electoral Code must provide equal opportunity to political parties and candidates. It requires state authorities to be impartial toward them and to apply the same law uniformly to all, especially regarding (i) the electoral campaign, (ii) coverage by the media, especially the public media and (iii) public funding of parties and campaigns.

The Albanian Electoral Code has a significant number of provisions regarding these requirements. The election campaign is due to start 30 days before election day. The period of electoral silence starts the day before election day until the close of voting (Article 77). During the election campaign the Public Radiotelevision provides free time for all political parties registered with in the CEC (Article 80.81). The division of this free time is based on the principle of political parties "strength", which is estimated according to the percentage of assembly seats that each party has. For parties not represented in the assembly the code provides for a 10 minutes public radio and television free time. The electoral code establishes clear rules for campaign coverage in private radio and television (Article 84). To monitor the implementation of these provisions the Electoral Code provides the establishment and functioning of the Media Monitoring Board, as a technical institution, with distribution throughout the Republic.

The funding of electoral subjects by the state budget is done in accordance with the requirements of Articles 86, 87. This provisions are in line the guidelines of the Code of Good Practice in Electoral Matters. The use of other public resources for electoral subjects is prohibit (Article 88).

Articles 89,90 and 91 define rules for non-public funds for electoral subjects. These provisions are intended to prevent suspicious funding and to narrow the effects of this funding in the post-election behavior of the political parties.

Legal provisions on auditing of funds and spendings of election campaigns (Article 91, 92) are intended to increase the level of transparency.

Although, elctoral practices have shown an important gap between law requirements and thier implementation by state authorities, political parties and other stakeholder part of the electoral process is at a high level.

\subsubsection{Equality and national minorities}

The electoral legislation should create opportunities for political parties representing national minorities. It is recommended to guarantee reserved seats for national minoritiesor exceptions to the normal seat allocation criteria for parties representing national minorities. .

The Albanian legislation allowsthe establishment of political parties representing national minorities. These parties are treated at the same way as all other political parties. Election legislation does not impose to any voter to show his affiliation to a national minority. The guidelines of the Central Election Commission require the organization and conduct of information, education and awareness campaigns for national minority communities to participate in electoral processes.

\subsubsection{Equality and parity of the sexes}

Legal rules requiring a minimum percentage of persons of each gender among candidates should not be considered as contrary to the principle of equal suffrage. Such a legal stipulation is encouraged to be part of the electoral legislation. It can serve as an indicator for assessing the society democratic development level. Gender representation is subject of two different groups of provisions of the Electoral Code of the Republic of Albania:

(i) Provisions governing the composition of election commissions (Article 14, paragraph 1 (b), Article 29, paragraph $1\left(c_{)}\right)$),

(ii) Provisions conditioning gender representation in the list of candidates representing political parties and coalitions (Article 67, paragraph 5)

The provision providing gender representation in the list of candidates is set up for the first time in the Albanian electoral legislation by law No. 10019 dated 29.12.2008. Despite the spirit of this provision, a careful analysis and its implementation in practice shows that, in fact, this legislative solution failed to achieve the objective - the representation of women in Parliament, with a rate as close as possible to the 30 percent quota. The requestof at least 30 percent of the constituency candidates list and / or one of the three first names of this list ought to belong to each gender created space for political parties to devise candidates list in such way for women to be impossible to be elected. The results of the Assembly elections of June 2009 proved that. Only 12.4 percent of the deputies were women.

The amendment of the Electoral Code adopted by Law no. 74/2012 dated 19.07.2012 changed this provision. 
However it must be said that, despite the increased opportunities for gender representation, this was not the best solution. Political parties have sufficient space to circumvent this requirement and to implement it only formally, without any effect on the election results. This provision will allow them to enlist women / girls at the end of the list and consequently, chances to be chosen for them, are almost zero. This is shown by the result of the Assembly election held on 23 June 2013. This provision was substantially changed by law no. 31/2015.

\subsection{Free suffrage}

The fulfillment of this standard requires:

\subsubsection{Freedom of voters to form an opinion}

State authorities must observe their duty of neutrality. The electoral legislation should provide provisions that enable the non-abusive use of the media, equal rights to manifest, financing of parties and candidates. Public authorities should create conditions for voter to have information on the voters lists, political parties should inform voters about candidates registered. Election legislation should provide sanctions for violations of neutrality and freedom of voters.

The current Albanian legilsation contains provisions which enable compliance of these requirements. Various provisions expressed in the Civil Code, Criminal Code, Civil Status Laws Package, Basic Register of Citizen and Central Election Commission Guidelines act in addition to them.

The Electoral Code provides every electoral subject with the right to make electoral propaganda (Article 78, paragraph 1). Provisions for campaign coverage by public and private media are in accordance with the standards required by the Code of Good Practice in Electoral Matters.

The provisions under which the voters list must be compiled (Part III, Chapter I, Article 44 - Article 57), envisage the obligation of authorities to draw up these lists, to inform voters (Article 52) and electoral subjects (Article 60).

The Electoral Code foresees penalties in case of non-compliance with provisions regarding equality of electoral subjects in campaigning, impartiality in media coverege, parties funding etc.. (Article 84, paragraph 9, Article 171, paragraph 3, Article 172, Article 173, Article 174)

\subsubsection{Freedom of voters to express their will}

Voting procedures must be simple. Voting by mail can be applied in cases of voters who are in hospital, in prison, voters with physical disabilities or living abroad. Electronic voting can be used only if it is safe and reliable. In cases of voting by proxy precise rules are needed. Mobile ballot boxes can be used only if very necessary.

For the fulfillment of this requirement the electoral code and instructions of the Central Election Commission provide legal procedures which enable a simple voting process, ballots are conceived in a format understandable to voters (how to vote information campaign were conducted by the Central Election Commission onall the electoral processes). For voters in hospitals, in prison, on military bases, the electoral code provides for the establishment of special voting centers (Article 59, Article 60) in these institutions.

Article 108 defines strict rules in order to guarantee the exercise of the right to vote for voters with physical disabilities.

Albanian legislation does not provide mobile voting boxes, voting by mail and electronic voting.

\subsubsection{Actions to combat electoral fraud}

Voting, evaluation and counting proceduresmust be transparent. They must take place in certain centers, with the participation of representatives of a number of parties and observers appointed by the candidates, who should have access to the records. Election results must be transmitted to the higher level in an open manner. The state must punish any kind of electoral fraud.

The Albanian legislator, because of the absence of mutual trust between the major political parties, has been investing heavily to develop legal procedures aimed at narrowing, to the maximum, spaces that can be used to carry out electoral frauds. The history of drafting electoral legislation is oversaturated with legislative solutions only to reduce opportunities for interpretations and electoral fraud instead of drafting " game rules" that will better enable an electoral process in accordance with the standards. This argument may also explain the persistence of all political parties for 
greater presence of their representatives at all levels of the election administration.

In view of this request, in many cases, political parties, especially the two major parties SP and DP, have not hesitated to implement legal solutions, which were only a consequence of political compromise, even by non-respecting constitutional requirements. This has been the case of the constitutional provisions defining the composition of the Central Election Commission in 2005 and 2007 election or the establishment of second and third level commissions with up to 13 members. The current Code provides for the presence of representatives of electoral subjects at all levels of the election administration as voting members or observers. Under this code, the entire election administration is based on the principle of representation and political balancing.

To increase transparency in the evaluation and counting process, that becomes concentrated, the Electoral Code provides the use of electronic technology support (Article 94).

Counting results and tabulation are broadcasted online, in real time, to the CEC. Counting is done by political parties representatives. Electoral subjects, who are not members of these counting groups, have the right to have observers with the right to to participate in the administration of this process (Article 116).

The Electoral Code provides penalties for those who interfere in the administration of the voting process and punishment for election administration members, in case of violation of legal procedures. Despite the fact that these legal are consistent with the Code of Good Practice in Electoral Matters, in some cases, they are strained or overloaded.

\subsection{Secret suffrage}

For the voter, secrecy of voting is not only a right but also a duty, non-compliance with which must be punishable by disqualification of any ballpaper whose content is disclosed. Voting must be individual. Family voting and any other form of control by one voter over the vote of another must be prohibited. The violation of secret suffrage should be sanctioned.

Albanian legislation states that: "Elections are conducted through free, secret, equal and direct suffrage ... Voters freely exercise the right to vote" (Law no. 74/2012, dated 19.07.2012, Electoral Code, Article 3, paragraph 2). In order to ensure this the Code provides voting procedures (Article 105, Article 106). These procedures are legal guarantees to fulfill the requirements expressed by the above provision (Article 3, paragraph 2).

Family voting and voting control are prohibited. This is clearly specified in the Code "... voters are checked in both hands if it is been marked with special ink or not, if yes, they are not allowed to proceed... a voter can just pick up a ballot and only once ... after receiving the ballot the voter enters alone in the secret room and marks the ballot ... the ballot must be folded in order not to be visible... and after casting the ballot the voters leaves the voting center ... (Article 105, Article 106).

The legislation is aligned with the requirements of the standards laid down in the Code of Good Practice in Electoral Matters. Despite this, it should be noted that between this legislation and its implementation subtle differences. In most of them, these differences are a result of a complex set of factors, such as social, history, culture, tradition, social psychology, economic and democratic development of the society. These factors, and not the legislation, are the causes that phenomena like family voting, group voting, etc .. are frequent in the electoral processes in Albania, especially in rural and suburban areas.

\subsection{Direct suffrage}

Albanian legislation provides only direct suffrage for both the Albania Assembly and local government bodies.

\subsection{Frequency of elections}

The Constitution of the Republic of Albania states that general election, normally, are to be held every four years. After the consitutional amendments (law no. 9675, dated 13.01.2007) local elections are also, normally, held once in four years.

\section{Poosible Improvements of the Electoral Legislation in Order to Better Approximate with the Code of Good Practice in Electoral Matters}

The drafting of electoral legislation in line with the implementation of the principles of the European electoral heritage and the Code of Good Practice in Electoral Matters, requires as a precondition the existence of a legislative field that enables 
respect for basic human rights, freedom of media and expression, freedom of movement within the country, freedom to assembly and freedom of association or organization for political purposes, including the creation of political parties. Albania's Constitution guarantees all these freedoms. Based in this, the current electoral legislation, significantly creates the necessary legal conditions for holding elections in accordance with the principles and standards for free and democratic elections. Meanwhile, referring to the spirit but also to the content of the Code of Good Practice in Electoral Matters, future developments of this legislation can aim at:

(i) Administration of elections by an impartial body According to the Albanian Constitution (Part XII, Article 154, 155), approved by law nr.8417, dated 21.10.1998, approved by referendum and promulgated by Decree 22.11.1998 nr.2260, dated 28.11.1998 of the President, the Central Election Commission is defined as a constitutional institution, without political representation. This legislative solution, which is based on the establishment of an impartial body for the organization and administration of elections, proved to unsustainable. Constitutional amendments (law Nr.9904, dated 4.21.2008) turned this institution as a concern and part of the Electoral Law. According to this law, this insitution is established now, based on the principle of political representation and political balancing. In the legislative context, in principle, such a solution does not oppose the request to have a neutral institution but, in practice, cases of electoral decision-making based on political affiliations of its members are not rare.

In any case but, even more when the electoral administration, at all levels, are formed on the basis of the principle of political representation and political balancing, it is imperative for all electoral subjects to have their representatives in the administration, as members of commissions or observers. Meeting this requirement has been one of the most controversial issues. Regarding this requirment, members of small political parties, part of the assembly, used, as a mean of democratic pressure, the hunger strike (February 2008). The establishment of an election administration based on the principles of the public administration is one of the expected developments of the Albanian electoral legislation.

(ii) Election administartion should be stable

The Venice Commission recommends that entities that have the right to appoint members of electoral commissions should not have the right to dismiss them at will without any valid motivation. This recommendation has not been taken into account by the Albanian political class. Provisions of the Electoral Code that entitles political parties to change the members of election commissions at any time without any obligation for justification should be abolished.

(iii) Decision making in election commissions should be made by qualified majority or consensus.

Regarding the Central Election Commission the Election Code defines two ways for decision making. A qualified majority is required (voting "for" not less than 5 members of the Committee) for decisions related to (a) mandate distribution for each constituency, (b) the receipt of the appeal against the approval of the aggregate table for the outcome of elections and for decisions on appeals against decisions of the CEAZ for the outcome of local government elections, (c) request for declaring the invalidity of elections in or more polling stations, (d) election invalidaion of a constituency or across the country and their recurrence, (e) normative acts for election related issues, $(\mathrm{f})$ proposal for dismissal of CEC member, $(\mathrm{g})$ approval of the organic structure of the CEC, as well as its regulation (h) allocation of seats for each constituency, (i) appointment of election administration areas.

All other CEC decisions are taken by simple majority.

Second and third level commissions decide by simple majority voting. The secretary has no right to vote.

The Albanian electoral legislation does not comply with the recommendation given by the Venice Commission regarding decision making procedures of election commissions. Election practice has shown that this is the best solution, in terms of Albania, solution which reduces opportunities for blocking minorities, which can be politically activated even in unjustifiable cases.

(iv) Legislation should ensure an effective system of appeal

Referring to the experiences and the need to reflect in order to fully complete the requirements of the Code of Good Practice on Electoral Matters and as it is highlighted by the international observer mission (Final Report, Elections, 2013), the Electoral Code should be further process provisions that guarantee the rights of all interested parties to submit an administrative appeal against decisions and actions of election commissions, improper actions during the campaign, irregularities on Election Day and results. It is necessary to reduce the deadline for adjudicating pre-election cases by the College, enable the right to judicial appeal and the publication of all the decisions of the Electoral College. As recommended by international observers 
Constitutional Court must not improperly deny jurisdiction to review decisions of the Electoral College and Assembly decisions for the violation of constitutional guarantees of due process; the law should provide accelerated deadlines for filing and adjudicating claims relating to the elections to the Constitutional Court. Besides these, in an effort to harmonize legislation with the requirements of the Code of Good Practice on Electoral Matters, the adjudication of appeals against decisions of second and third level commissions can be treated by District Courts.

\section{Conclusions}

Albanian electoral legislation is mostly aligned with the requirements and recommendations of the Code of Good Practice in Electoral Matters of the Venice Commission (EC).

For further increasing this consistency, the legislative process has to pay due attention to issues related to:

(i) favorable conditions for exercising the right to vote for voters residing abroad,

(ii) voting equality and equal chances in electoral race for all electoral the subjects and candidates,

(iii) gender representation,

(iv) facilities for voters with physical disabilities,

(v) establishment of a realiable and impartial election administration,

(vi) decision-making by qualified majority or consensus for election commissions,

(vii) the establishment of a more effective system for complaints and appeals,

(viii) increased opportunities for the involvement of the judicial system, district courts and Constitutional Court on election issues

\section{References}

Code of Good Practice on Electoral Matters nr. 190/2002. CDL-AD (2002) 23rev. Komisioni Evropian per Demokraci permes Ligjit (Komisioni i Venecias). Keshilli i Europes. Venecia, 18-19 Tetor 2002

Kodi Zgjedhor i Republikës së Shqipërisë. L i g j Nr. 10 019, datë 29.12.2008. Azhornuar me ligjin nr. Nr. 74/2012

Joint opinion on amendments to the Electoral Code of the Republic of Albania. Opinion 435 / 2007. CDL-EL(2007)018. the Venice Commission and the OSCE/ODIHR. Strasbourg/Ëarsaë, 5 July 2007

Joint opinion on the Electoral Code of the Republic of Albania. Opinion No. 513 / 2009. CDL-AD(2009)002. Adopted by the Venice Commission at its 78th plenary session (Venice, 13-14 March 2009. Strasbourg/Ëarsaë, 13 March 2009 